\title{
Food-sharing in the distributed use economy
}

\author{
Olga Saginova ${ }^{1, *}$, Dmitry Zavyalov ${ }^{1}$, Natalia Kireeva $^{1}$, Nadezhda Zavyalova $^{1}$, and Yury Saginov ${ }^{1}$ \\ ${ }^{1}$ Plekhanov Russian University of Economics, Moscow Russia
}

\begin{abstract}
Sustainable development values and concepts of responsible consumption, sharing, waste-free production and recycling are becoming more and more popular among organisations and consumers. Though food-sharing has not yet become as popular as car-sharing, it aims to solve important social food policy problems of decreasing food waste and redistributing food to support those in need. Basing on research literature, and publications in business media the paper presents the results of content analysis of materials from food-sharing platforms and websites in Russia. Authors compare foreign best practices, identify the main food-sharing models: exchange with monetary compensation, gratuitous transfer (charity), and food-sharing within the neighbouring community Problems and unresolved food-sharing issues are explained, such as lack of information about available options of food-sharing, low trust of consumers to the quality of food being shared and perception of using charitable food stock as something shameful. The paper maps possible directions for the development of food-sharing considering the existing international experience.
\end{abstract}

\section{Introduction}

The concept of sustainable development and its accompanying concepts of social responsibility, responsible consumption, waste-free production, reuse, and recycling are gradually changing the business models of manufacturers, distributors, and other market players, and affect consumer behaviour. The development of information and communication technologies allows consumers to change and broaden their economic activity. Peer-to-peer exchanges (P2P) are developing and becoming more diverse, allowing consumers to transfer ownership or provide other users with access to unnecessary or temporarily unused assets. Based on this growing intensity of peer-to-peer exchanges and economic activity of consumers, various services have emerged and are developing, connecting those who own assets and resources with those who need them. The sharing economy has a positive impact on the environment and society. It helps to reduce waste, allows to build new social contacts, creates new jobs, and leads to efficient use of resources [1].

The most advanced sharing practice is currently carsharing and ride-hailing, i.e., ordering a car with a driver on demand using a mobile app. Collaborative consumption and peer-to-peer exchange of food and clothing are still not as developed and popular. However, these areas of development make a significant contribution to the conservation of natural resources, the promotion of reasonable consumption and supports the values of sustainable development.

\section{Materials and methods}

In this article, basic concepts related to joint food consumption are defined, the existing models and characteristics of food-sharing are analysed, and the socially significant directions for the development of entrepreneurial initiatives in this area are identified. The analysis is based on the open sources information: study of publications in scientific and business journals and mass media and the data from the websites of available food-sharing services in Russia. Content analysis of the data collected was undertaken, results were compared with existing body of research publications in Scopus indexed journals in the period 2015-2020.

\section{Results and discussion}

\subsection{Food-sharing in the distributed use economy}

Business and scientific publications describe the new models of economic activity and consumer interaction. At the same time, different terms used to refer to the same or similar concepts of peer-to-peer exchanges, transfer of access to assets, joint ownership and use of these assets make the analysis and understanding cumbersome and often confusing. The concept of distributed use economy was introduced and justified to overcome the concepts diffusion and overlap [2]. In this article, we will focus only on the concepts directly related to the distribution and exchange of food products

\footnotetext{
* Corresponding author: $\underline{\text { saginova.ov@,rea.ru }}$
} 
and will use the term "Distributed use economy" to define the overall concept of providing access or ownership transfer via digital platforms to provide other users with access to unnecessary or temporarily unused assets.

The emergence and development of the distributed use economy and the growth of sustainable and shared consumption have led to innovations in business models supported by digital technologies [3]. Innovative companies are implementing digital technologies to solve environmental, social, and economic problems [4, 5]. Changes are being implemented in the food industry to reduce food losses and waste [6,7]. One of the most innovative business models in the food industry is webbased food-sharing platforms and/or mobile applications that help reduce food waste $[8,9]$ and allow users to share food and food products $[10,11]$.

Experts estimate that a third of the world's food production (about 1.3 billion tons) is lost or discarded annually $[12,13]$. In Europe, the volume of food waste is estimated at about 88 million tons per year, and with unaccounted food waste, the figure can be increased by $30-40 \%[14,15]$. This problem is also important for Russia, where 17 million tons of food is sent to waste every year, while $13.5 \%$ (BBC, 2020) of the population (about 20 million people) live below the poverty line [8]. Given the high level of food waste, to reduce it and related environmental, social, and economic problems, food-sharing platforms are critically important for sustainable development, reducing waste and promoting a model of reasonable consumption and sustainable development values in society $[10,16,17]$.

The very concept of food-sharing includes a variety of practices aimed at preserving and redistributing food. As in the distributed use economy, in general, foodsharing includes both peer-to-peer and multi-peer exchanges, the source of food products can be consumers themselves (P2P), commercial and non-profit organizations (B2C), intermediaries and aggregators are business structures, charitable foundations and public organizations. The goals of food sharing are also diverse: from helping the poor, disposing of products whose shelf life is coming to an end, to cooking and tasting dishes of national cuisine together.

The platforms of the aggregator companies or the mobile applications developed by them unite all participants of the exchange, creating a secondary market for the redistribution of surplus food, simplifying the process of exchange, gratuitous transfer, and sale of food. Food sharing can be considered as a sustainable business model of the distributed use economy [18]. Since consumers play a significant role in the exchange, creating value together with organizations and with each other, food exchange platforms and especially peer-topeer (P2P) platforms are gaining popularity, as they rely on the benefits of joint activities and strengthening social interaction in networks and communities [18].

\subsection{Food sharing as a solution to a socially significant problem}

With the growth of consumption and the increase in food production, our society faces a serious problem - a wasteful attitude to food. While some people do not have enough money for the essential food, others buy too many products, which leads to their irrational use and the formation of left-overs and waste. The purpose of food sharing is to exchange and redistribute food between people, transfer unused food from hotels, restaurants, canteens, and other public catering establishments for free or at a significant discount.

However, food-sharing is not limited to charity. Another goal of food-sharing is the rational use of food, the prevention of waste. When people or companies buy an excessive amount of food that they cannot consume, they can pass the excess on to someone else rather than throw it away, harming nature.

According to the existing regulations, unused food products that have expired should be disposed of. In the Russian Federation, the disposal of unused food is regulated by three laws:

1. Federal Law No. 89-FZ," On Production and Consumption Waste," defines the goals and basic principles of the state policy in the field of waste management.

2. Federal Law No. 52-FZ," On the sanitary and Epidemiological Welfare of the Population," defines sanitary requirements for the collection, accumulation, transportation, processing, disposal, neutralization, and disposal of industrial and consumer waste.

3. The Code of Administrative Offences No. 195-FZ establishes liability for non-compliance with environmental and sanitary-epidemiological norms and rules in waste management, liability for contamination of soil and forests with industrial and household waste and provides for liability for violation of veterinary and sanitary rules for the collection, disposal, and destruction of biological waste.

According to the law "On the Protection of Consumer Rights," when the expiration date comes, food is considered unusable and cannot be sold or even distributed for free to anyone. According to the law "On the quality and Safety of Food products," leftovers and ready meals cannot just be thrown into the trash bin. They must be disposed of according to the rules, concluding a contract with a company that has a license for disposal. These rules and laws show that the timely redistribution of surplus food through the food sharing system not only transfers food to those in need but also allows companies to avoid the cost of waste disposal.

\subsection{Food-sharing models}

The analysis of the sites of food-sharing platforms and services revealed three main models of food exchange [3]:

1. Exchange with monetary compensation,

2. Gratuitous transfer (charity),

3. Sharing within the neighbouring community. 
The first model (exchange with monetary compensation or sale) includes both not-for-profit and for-profit types of sales. Such an exchange implies that food is transferred for the purpose of obtaining some profit or at least covering the cost of food. This is a B2C model: companies that produce or sell food (restaurants, hotels, bakeries, etc.) offer to sell products with expiry dates soon, at a price or at a significant discount. These organizations may use digital platforms (websites or apps) where they can publish daily information about products that they are willing to sell on such terms. Applications are usually created by aggregator organizations that combine the offers of various companies and suppliers. Aggregators can either receive a percentage of each sale or charge organizations that use the app. This is beneficial to all participants of this process: companies receive some income and do not spend on the disposal of leftover food, customers buy food much cheaper than it usually costs, aggregators earn money by ensuring that buyers and sellers can contact each other.

According to this model, the existing apps in Russia that provide the opportunity to buy food in restaurants, cafes, and bakeries, like Eatme, works. This service allows purchasing food products at a discount of up to $75 \%$. The service was launched in 2019 in Moscow, and now it also operates in St. Petersburg, Nizhny Novgorod, Sochi, Kazan, Yekaterinburg, Khabarovsk, Ulyanovsk, and Vladivostok. Most of the service is used in St. Petersburg, where it includes 231 restaurants; in Moscow it is used by 162 restaurants [19].

The monetization model of this service is based on a subscription: companies wishing to join this service purchase a subscription worth 399 rubles per month for a 12-month period or 599 rubles per month for a 1-month period. The aggregator receives $1.5 \%$ of the order price. Restaurants post information about dishes; if they have food with a $50 \%$ discount or higher, the service will allow them to post their entire menu to attract new customers [20].

The "free exchange" or "charity" model is commonly used by not-for-profit organizations that collect food from companies and households and distribute it for free to those in need. In some cases, not-for-profit organizations create food donation points where anyone can bring surplus food. These food donation points can be set up in supermarkets for which such partnerships are beneficial, as people sometimes buy food from these stores to donate it, resulting in an increase in sales. This is also convenient for those who want to donate their extra food because supermarkets are usually located near their residence places, so they do not need to travel far to donate food to charity. This model is useful for the society: it provides food to the poor, reduces food waste, and raises public awareness of poverty and environmental issues.

Initially, this model was used to create food banks. They first appeared in the United States in the XX century $[10,21]$ and then spread to other countries. Today, they are present all over the world [22]. The first food bank in Russia was established in 2012, it is called the "Rus Food Fund." Today, the organization is one of the top 5 charity foundations in Russia and works with manufacturers, retail chains, and public catering enterprises that regularly transfer their products from factories and warehouses to the foundation under gift agreements. Organizations donate surplus products that are suitable for consumption in accordance with the current legislation.

The third model (neighbouring community exchange) assumes that food is exchanged between members of the neighbouring community. Such a community can bring together people who live in the same area or people who are concerned about food waste. A group of people can use web-based platforms to share food. For example, two female entrepreneurs (Saasha Celestial-One and Tessa Clarke) from the UK in 2015 created the Olio app, with which anyone can post information about the products they are willing to hand over. According to the organization's website, more than 2.5 million people have already used the app and shared almost 10 million food servings.

There is no such app or website for food-sharing in Russia yet, but there are groups dedicated to sharing food and cooked dishes in social networks (VKontakte and Facebook). The largest group in Russia consists of more than 70,000 people from Moscow and St. Petersburg [19].

The food-sharing charity model is similar in purpose to the food saving movement, an environmental movement to save food. In Moscow and St. Petersburg, dozens of teams of food savers are actively working. In different cities, food saving has acquired some individual features: in St. Petersburg, volunteers save tons of fruits and vegetables from vegetable stores, and in Moscow, priority is given to the distribution of products to the needy. The main goal of the movement is to save, take out and distribute the maximum amount of food so that it does not go into the trash bin.

Food-sharing also includes models that are attractive to the hospitality and tourism industry. The international service EatWith is successfully developing, helping tourists to find a company for dinner or tasting dishes of national cuisine in a foreign country. Currently, the list of international locations includes 28 countries. The service operates on a for-profit basis: if you want to come to someone for dinner in a foreign city, you must pay the amount indicated by the host. To receive guests at home, the candidate goes through a selection procedure undertaken by representatives of the service in his/her country. EatWith meets several objectives at the same time: it helps tourists get to know the locals, taste local cuisine, and get advice on how to spend the best time in their city.

\section{Problems and directions of food sharing development}

Food-sharing platforms, and especially P2P platforms, are becoming increasingly popular and successful, as they are based on social networking within communities [3]. However, the development of food-sharing is not without difficulties and problems. Some studies have 
shown [23] that even if people have a positive attitude towards distributed use economy systems, many do not use them, which indicates that there is a discrepancy between attitudes and actual behaviour. Scientific publications indicate that the behavioural response focuses mainly on consumers' perception of beliefs and values, such as sustainability, environmental awareness, and corporate social responsibility $[13,23]$.

Food-sharing can be a behavioural response to the values of sustainability, environmental awareness, and social justice, which is based on the principles of corporate social responsibility, community social support. What is also important is consumer familiarity with and willingness to use food-sharing platforms. In this regard, it is necessary to raise awareness about foodsharing services. The analysis of the literature has shown that people often do not understand the benefits and importance of food-sharing. Also, some simply do not know about other options for using food surpluses other than their disposal. Therefore, it is necessary to conduct a broad information campaign, where specialists (for example, owners or managers of food-sharing services) will explain in detail what services for the use of surplus food exist, why socially responsible consumer behaviour is a new trend, and how it will help improve our lives.

Another problem identified during the analysis is the lack of trust between buyers/recipients and sellers/suppliers. Suppliers are afraid that the transfer of surplus food will be associated with additional costs of time and money, recipients are afraid that they will receive low-quality, spoiled products. The reason for this lies in the lack of awareness of the participants of the food-sharing. Restaurants and other food suppliers do not publish information about the production dates and shelf life of products, so it is impossible to judge the quality. Aggregator companies, on the one hand, can make it mandatory for suppliers to specify all deadlines and dates, but on the other hand, this may scare off potential participants, especially charitable transactions.

One more problem with the development of foodsharing in Russia is that Russians are often ashamed to buy second-hand or charity products. They believe in the stereotype that second-hand shops and rental services are created for the poor. Volunteers of the Eatme platform described situations when needy people were embarrassed to openly take free food. To overcome this stereotype, collaborative consumption and sharing should be popularized in general, showing its benefits and consequences for the environment and society.

The analysis of the international practice of foodsharing shows the expansion of the scope of sharing. In addition to the exchange of food and cooked dishes, food-sharing services can provide the possibility of collecting surplus fruits and vegetables, provide spaces (both public and private) for growing nutritious plants, teach the cultivation of vegetables and fruits, organize the exchange of cooking accessories, cooking training, and the opportunity to taste national cuisine prepared by residents [24].

\section{Conclusion}

The sharing economy has a high potential for growth and development. People are interested in the concepts of shared consumption, and they are ready to participate. A review of the literature and existing food-sharing practices showed that, in general, consumers would participate more actively in the exchange of food if they were conveniently organized, and information about their social significance and beneficial impact on the environment was more widely and actively disseminated.

The general perception of food-sharing as free products for the poor significantly limits the ability to distribute such services and attract both consumers and suppliers.

Greater awareness of the benefits of food-sharing for food producers and suppliers can reduce not only their waste but also the cost of waste disposal, thereby contributing to the preservation of natural resources.

The results of the analysis of applications and websites of food-sharing services available in Russia indicate that people have little awareness of these services. Most of them are available only in Moscow and St. Petersburg and do not promote their services among both food suppliers and consumers.

The topic of food-sharing as part of the distributed use economy and an option of food policy needs further research. One of the possible research directions can be the analysis of digital planforms' role in promoting foodsharing services, and a survey of young consumers' attitudes to food-sharing.

The authors are grateful for assistance in collecting data to the student of Plekhanov Russian University of Economics Y.Orishko

\section{References}

1. G. Görög, The Definitions of Sharing Economy: A Systematic Literature Review, Management, University of Primorska, Faculty of Management Koper, 13 (2), 175-189 (2018)

2. Yu.L. Saginov, D.V. Zavyalov, O.V. Saginova, Ekonomika raspredelennogo polzovaniya: osnovnye ponyatiya, opredeleniya, kharakteristiki [Distributed use economy: basic concepts, definitions, characteristics], Russian Journal of Innovation Economics, 3, 1403-1424 (in Russian) (2020) DOI: 10.18334/vinec.10.3.110726

3. L. Michelini, L. Principato, G. Iasevoli, Understanding food sharing models to tackle sustainability challenges, Ecol. Econ., 145, 205217 (2018)

4. S. Alfiero, M. Christofi, A. Bonadonna, Street food traders, farmers and sustainable practice to reduce food waste in the Italian context, Br F J., 122 (5), 1361-1380 (2019)

5. C. do Stangherlin, J.L. Duarte Ribeiro, M. Barcellos, Consumer behaviour towards suboptimal food products: a strategy for food 
waste reduction, Br F J., 121 (10), 2396-2412 (2019)

6. S. Yu. Kazantseva, Fudshering $\mathrm{v}$ torgovle produktami zdorovogo pitaniya [Foodsharing in the trade of healthy food products], Journal of Economy and Entrepreneurship, 10 (111), 665667 (in Russian) (2019)

7. J. Rosenlund, Å. Nyblom, H. Matschke Ekholm, L. Sörme, The emergence of food waste as an issue in Swedish retail, Br F J, 122 (11), 32833296 (2020)

8. L.V. Berketova, S.S. Volodina, Fudshering - kak ekologichnyy sposob ispolzovaniya produktov pitaniya [Food sharing - as an eco-friendly way to use food], Bulleten nauki i praktiki [Bulletin of science and practice], 1, 253-259 (in Russian) (2020)

9. J. Harvey, A. Smith, J. Goulding, I. Branco Illodo, Food sharing, redistribution, and waste reduction via mobile applications: A social network analysis, Ind. Mark. Manag., 88, 437-448 (2020)

10. Botalova, Fudshering: ekonomicheskie, ekologicheskie i sotsialnye aspekty yavleniya [Foodsharing: economic, ecological and social aspects of the phenomenon], Vector of economy, 1 (43), 69 (in Russian) (2020)

11. P.M. Falcone, E. Imbert, Bringing a sharing economy approach into the food sector: The potential of food sharing for reducing food waste, Food waste reduction and valorisation, 197-214 (2017)

12. A.M. Agapkin, N.A Ibragimova, Ratsionalnoe ispolzovanie pishchevyh produktov $\mathrm{v}$ formate fudsheringa [Rational use of food in the format of food sharing], Journal of Economy and Entrepreneurship, 12 (113), 651-653 (in Russian) (2019)

13. C.P. Lamberton, R.L. Rose, When is ours better than mine? A framework for understanding and altering participation in commercial sharing systems, J Mark, 76 (4), 109-125 (2012)

14. M. Caraher, S. Furey, The economics of emergency food aid provision: a financial, social, and cultural perspective (Palgrave Pivot, 2018) DOI: $10.1007 / 978-3-319-78506-6$

15. M. Mourad, Recycling, recovering and preventing «food waste»: Competing solutions for food systems sustainability in the United States and France, J. Clean. Prod., 126, 461-477 (2016)

16. S.G. Mackenzie, A.R. Davies, Share it: Codesigning a sustainability impact assessment framework for urban food sharing initiatives, Environmental Impact Assessment Rev, 79, 106300 (2019)

17. A. Mazzucchelli, M. Gurioli, D. Graziano, B. Quacquarelli, C. Aouina-Mejri, How to fight against food waste in the digital era: Key factors for a successful food sharing platform, J Bus Res, 124, 47-58 (2020) DOI: $10.1016 /$ j.jbusres. 2020.11 .055
18. L. Michelini, C. Grieco, F. Ciulli, A. Di Leo, Uncovering the impact of food sharing platform business models: A theory of change approach, Br F J, 122 (5), 1437-1462 (2019)

19. Yu.A. Orishko, Uslugi fudsheringa v Rossii [Food-sharing services in Russia], Human Capital and Professional Education, 4 (34), 125-127 (in Russian) (2020)

20. O.V. Saginova, Yu.A. Orishko, Modeli sovmestnogo ispolzovaniya prodovolstviya [Food-sharing models], Ekonomika, predprinimatelstvo i parvo, 11, 2 (2021) DOI: 10.18334/epp.11.2.111587

21. G. Riches, Food banks and the welfare crisis (James Lorimer \& Company, 1986) Available at: https://www.savers.com/sites/default/files/reuse_r eport_2018-savers.pdf (accessed: 12.01.2021)

22. M. Caraher, A. Cavicchi, R. Wells, UK print media coverage of the food bank phenomenon: from food welfare to food charity? Br F J, 116 (9) (2014) DOI: 10.1108/BFJ-03-2014-0123

23. J. Bielefeldt, J. Poelzl, U. Herbst, What's mine Isn't yours - barriers to participation in the sharing economy Die Unternehmung, the Swiss Journal of Business Research and Practice, 70 (1), 4-25 (2016)

24. R. Davies, R. Legg, Fare sharing: interrogating the nexus of ICT, urban food sharing, and sustainability, Food Cult Soc, 8014, 1-22 (2018). 